\title{
A Conversation with John McMillian Ben Holtzman
}

John McMillian is among several young scholars who are leading the production of a revisionist, bottom-up history of the New Left in the 1960s. He is the coeditor (with Paul Buhle) of The New Left Revisited (Philadelpia: Temple University Press, 2003), an award-winning volume that challenges the dominant narrative of New Left history and (with Timothy Patrick McCarthy) The Radical Reader: $A$ Documentary History of the American Radical Tradition (New York: The New Press, 2003), a widely-adopted volume that has helped make the radical tradition of American history more accessible to students and the public. Along with Jeremy Varon and Michael S. Foley, McMillian has recently become a founding co-editor of a new academic journal, The Sixties: A Journal of History, Politics and Culture, which will be published by Taylor and Francis beginning in June 2008. McMillian also lectures in the Committee on Degrees in History and Literature at Harvard University. His book, Tom Paine's Children: The Sixties Underground Press and the Rise of Alternative Media, is forthcoming from Oxford University Press.

The interview took place on 17 September 2005, in New York City's Central Park.

Ben Holtzman: Can you talk a little bit about your upbringing?

John McMillian: Really?

BH: Yes, I'm interested. Your background, growing up, things like that.

JM: Well, I was adopted and I was raised by very kind and generous parents. Neither of them are connected to the worlds of scholarship or academia. But at an early age I was a precocious reader. By high school, I had read about every book that had ever been published about the Beatles-or at least every book I could get my hands on, and there were a bunch of them. And I was interested in Abbie Hoffman, the Black Power Movement. I think it was this layperson's interest in the music and spirit of the Sixties that later helped me decide that I wanted to become a historian. I was a lousy student in high school. I had lots of discipline problems and I never got good grades. I couldn't even get into a decent state school, so at first I went to a community college, [and] then I transferred to Michigan State University when I was nineteen. It wasn't until I was in my early twenties that I decided that I wanted to go into academics and become a thinker, a writer. So I was a bit of a late bloomer. But, like I said, I always had this passionate interest in reading and [...] the Sixties. I came to Columbia and I was originally intending to study African American history with Eric Foner, I was going to 
focus on slavery and antebellum race relations. However, during my first year of graduate study I did this research paper for Alan Brinkley on the New Left and I realized that there was an awful lot of work to be done on the field, and I was excited to discover a great wealth of primary source material that hadn't been examined by scholars before. Meanwhile, I made some good friends, like Jeremy Varon $^{1}$ and Dave McBride ${ }^{2}$ and Kevin Mattson, ${ }^{3}$ who were all doing similar work and I liked the idea of being part of this community of scholars. I realized that the Sixties was really my first love, although African American history remains very important to me.

BH: I want to go back to some of those things, but moving forward, can you talk a little bit about going to graduate school and what it was like? What you were expecting, how it was different, what was disappointing, what was rewarding?

JM: I had incredible status anxiety. I did a Master's degree at Michigan State a couple years after undergrad, and it was a good program. I had professors like Harry Reed and David Bailey, who were just wonderful teachers. But I recognized that if I wanted to have a career as a historian, I needed to go to a better school, so I transferred into Columbia's Ph.D. program. But I still felt a bit like a fish out of water, because, as I told you, my parents weren't academics. I grew up in a small, isolated community. I'd never even been to New York. So I didn't come from any kind of high-powered or cosmopolitan background the way a lot of my peers did. And then initially, academic language didn't come easily to me. I knew I had some skills as a reader and writer, but I hadn't had much training in American History, and I just I didn't know an awful lot. Of course, at the same time, I was thrilled to be at Columbia, and I was in awe of some of my professors-I still am, in fact. And as a result I worked incredibly hard for those first couple of years. Unfortunately, the graduate student community didn't really appeal to me all that much. It was just very competitive and serious. Compared to other programs, I would not describe Columbia's history department a warm and fuzzy place.

BH: You've actually mentioned that you would have dropped out were it not for your relationship with Manning Marable. ${ }^{4}$ I'd like you to talk a little bit about that relationship, but I'd also like you to discuss how you almost came to the point [of] dropping out.

JM: I would have dropped out because I'd come into the program unfunded, and gradually it began dawning upon me that this was a ludicrous thing to have done - the most negative capital investment imaginable. Nowadays, all of Columbia's history graduate students come in with funding, but they used to have a system where you had a fellowship, or you didn't. And if you didn't, there was no way of ever getting one-you were just unfunded and were expected to pay $\$ 120,000$ to 
get your degree. But when I arrived in 1996 the situation was just changing, so it was possible for people like myself who came in without funding, and who did well in their first year, to secure teaching fellowships in subsequent years, and T[eaching] A[ssistants] got tuition waivers. Anyhow, right away, Manning hired me to work at the Institute for Research and African American Studies [of which Dr. Marable is founder]. So, the financial support was crucial. The financial stresses that graduate students face are huge and Manning always understood that. And whereas some of the history faculty sometimes seemed a little bit remote, and the graduate students seemed competitive, the Institute was the opposite. There was a real sense of warmth and fellowship. Manning was just friendly and funny and we had lots of hallway conversations; he always took an interest in our personal lives. He'd ask you questions about your family, where are you from, what you like to do. He'd have us over to his apartment or buy us lunch once in awhile. It was a really neat community. And everyone there was doing politically engaged work and they were unabashed about it. In fact, that was the whole point of the Institute: it was meant to build connections between academe and the community. So that appealed to me as well.

BH: In other writings you've done about your experience as a graduate student at Columbia, you've discussed the apathetic nature of history graduate students. You've noted that with the (large) exception of the recent union organizing campaign, in your first five years at Columbia, you witnessed only one example of formal cooperation among left history grad students (a short-lived Marxist reading group). ${ }^{5}$ Why do you think that was the case? You've mentioned the competitive nature of graduate school, but even being competitive academically wouldn't necessary prevent political activity from occurring. Why do you think there was the lack of political cooperation or organizing?

JM: I think it reflects the resignation and apathy in the rest of society. There's plenty of left wing activity going on today, but no major social movement that's really inspiring and politicizing people. Additionally, graduate school is very difficult, competitive, and time-consuming, so people are reticent to get involved with activities they perceive as distracting. That was one of the reasons it was hard to get people involved in the union. I can't tell you how many people I talked with who agreed with unions in principle, who agreed that graduate students were getting screwed in various ways, and agreed that an academic labor movement would be a good thing-yet they didn't feel they had the time or luxury of getting involved because of all the pressures they were facing. And I can empathize with that.

BH: But historically, is that [apathy and reticence] what we see among graduate students? It seems like there have been other times when graduate schools were 
hotbeds of radical activism.

JM: Well, the Sixties were one big exception. Paul Buhle makes the point that in the late Sixties history graduate students were in the lead of most left wing campus organizations. And I can think of people who went through Columbia in previous eras who were highly political, like Herbert Aptheker, Eugene Genovese, Howard Zinn, and then a little later, Eric Foner, Mark Naison, and Mike Wallace. But except for Naison-who wrote a really good memoir, White Boy-I don't know a whole lot about what all of their graduate student experiences were like. Certainly it's true that in this period, left wing historians and Black Power radicals bonded around this idea that they would create a "usable past" - this idea that America had an indigenous protest culture to be proud of, that a lot of people didn't know about. So uncovering that, and bringing it back to life, would serve a political purpose. And I think I'd have enjoyed being a graduate student in that period.

BH: Can you speak a little a bit more about the unionization campaign at Columbia? The struggle for a union for graduate students/workers at Columbia, along with Yale and New York University, seems to be perhaps the most active and contested.

JM: Yes, but I have been out of the loop for about four years now. Back around 1999, a couple of my colleagues_-Bev Gage ${ }^{6}$ and Kim Phillips-Fein ${ }^{7}$ and a few others - had talked about the need for a union, and then one day over beers at the West End we decided to start one! Obviously, there was a bit of hubris involved. We really didn't know what we were getting into. We had just talked about it and said, "Well, let's take the first step and announce that we're starting the union. " I think Kim took responsibility for making contact with the UAW. Bev and Kim and Jen Fronc ${ }^{8}$ and a few others probably did the most to get things going, but, very quickly, the campaign took on a life of its own. I was surprised at the amount of polarization it caused, because to me, whether or not we should have a union was a no-brainer. When we started, teaching assistants were being paid vastly different amounts of money for doing the same work! There were no job descriptions. There were no grievance procedures. How people found out about T[eaching] A[ssistant]-ships and/or got hired was very fuzzy and hard to understand. Sometimes the positions weren't advertised, so people couldn't reasonably compete for them. And some T[eaching] A[ssistant]s did very little work, while others suffered from crushing workloads. It just seemed really unfair. And in this country, workers are allowed to bargain collectively. In 2000, when the National Labor Relations Board (NLRB) ruled that TAs at private universities are employeeswhich is obviously the case-it opened the door for us to start a union, and we figured this would be very appealing to people. Hardly anybody that I knew 
thought that teaching assistants were treated very well.

But then there was a counter-movement, made up of students who vociferously opposed the union. This was rather disappointing, that graduate students couldn't imagine themselves as workers. I think there was something a little elitist about it. And I was surprised at how quickly the counter-movement gained momentum, although in hindsight, it wouldn't be surprising to learn that they had more than just tacit support from Columbia's administration. Anyhow, the history department was a locus of both the pro- and anti-unionization groups. Both efforts were university-wide, but no one would dispute that the most active people on both sides were history graduate students. I put in countless hours trying to build support for the union, and there was a real spirit of mutuality to everything we did. I have fond memories of all of this, but I've been terribly disappointed to see that the movement hasn't taken off the way that we hoped it would. Of course, the university spent millions of dollars fighting us; they hired unionbusting lawyers and waged an intensive [public relations] campaign, most of which was bullshit.

BH: You've mentioned why some people have been hesitant to get involved, but another thing that I am curious about is whether you think that some people were worried because of a potential backlash from professors, or from their department, or from other people who might have opposed this unionization campaign?

JM: I haven't heard that that happened at Columbia. Yale, though — that's a different situation. I know Yale grad students complained about being threatened and intimidated for supporting the union, though I don't know how much of it was verifiably true. But they claimed that this happened. At Columbia, I never thought any of our history department faculty was going to level repercussions against people who started the union. In fact, Columbia's history faulty is pretty left wing. I suspect Professor Foner is a little bit ambivalent about the union, but I'm certain he agrees that if we want one, we should be able to have one; it's an essential component of democracy. Professor Brinkley was chair of the history department when I was there and I applaud him for telling the Administration, early on, that the history department faculty would be neutral on this issue - that they wouldn't try and sway students one way or the other, or punish anyone who became involved.

BH: Let's discuss your work a bit. Can you talk a little more about how you came to shift from what you intended to study when you came to Columbia, African American history, to the study of Sixties radicals?

JM: Well, it just happened by accident. I took a research seminar my first year of grad school with Professor Brinkley and that produced a paper I enjoyed writing 
and was proud to get published. ${ }^{9}$ It was the first time I'd ever worked with primary sources and tried to contribute an original argument to the field. And as I explained before, I felt like this was the material that I was interested in to begin with. And so I could take this interest that I'd developed as a layperson, and put an intellectual gloss on it, and that was what was attractive to me.

BH: And what was it particularly about the topic? You weren't just studying the Sixties; you were studying radicals and activism.

JM: All of my research at that time was my way of thinking about what kind of stance I wanted to have in the academy. When I was studying African American history, I was looking at the role of white scholars in the Black Studies Movement of the Sixties, and how they responded to debates about the intellectual authority of white scholars to do this kind of work. Actually, the first graduate student paper I published-which I've taken off my c[urriculum] v[itae] because I'm embarrassed by it — was on the controversy that William Styron provoked with his novel The Confessions of Nat Turner. And then I wrote another piece on Robert Starobin, a white, New Left historian who studied slavery, and whose discoveries about the ways that some slaves were obsequious and accommodating to their masters clashed with the exigencies of the Black Power Movement. ${ }^{10}$ And I did some work with some letters that Mark Naison wrote when he was a white, leftwing graduate student at Columbia studying African-American history. ${ }^{11}$ Even at the time, I think I knew that I was interested in all this because I could see the parallels to my own situation, as a young white student wanting to build a career studying African-American history.

BH: Can you speak a bit more about some of those things that on a personal level you were dealing with?. What were the issues you were thinking through?

JM: Black Studies is still highly politicized. Let's face it: I had to think about whether, as a white scholar, I'd have a hard time getting a job in the field. And I should say, I would have had similar concerns in other fields as well. If someone wanted to teach Southern history, I suspect they'd be better off on the job market if they were Southern, for example. And even independent of this, I wondered whether this was the best area of inquiry for me. Of course I felt committed to the material; I never apologized for being white or felt that I couldn't do well in African-American history, but after I came to graduate school my interest in [African-American history] seemed secondary to my interest in the New Left.

Anyhow, to everyone's credit at the Institute-Manning, Johanna Fernandez, ${ }^{12}$ Michael Eric Dyson - they were all very welcoming to me. I think Manning certainly is inclined to appreciate anyone who is inspired by Black History, who understands the unfairness of racism, and who wants to work in the 
field, regardless of their background. So, I give them tons of credit. If I'd stuck with studying African-American history I'd have had a great deal of wonderful support. Then again, I almost got a tattoo of John Brown on my arm once (laughs).

BH: Can you speak a little bit about Sixties scholarship, particularly around the time that you were becoming involved with it-especially the scholarship that focused on activism?

JM: I didn't know the scholarship when I started. What I learned was that in the late eighties scholars produced a cluster of books that helped shape our thinking about the New Left, including Todd Gitlin's The Sixties, ${ }^{13}$ and James Miller's "Democracy is in the Streets". ${ }^{14}$ By the mid-nineties, when I started to study this stuff, they were already being called the "old guard" because their works had already begun to shape the research designs for lots of subsequent studies. And that's a real testament to their influence. Although their books are penetrating and beautifully written, I think most historians would agree that they focus overmuch on the leadership of SDS [Students for a Democratic Society] (which was the main New Left organization) and they pay too much attention to the early Sixties, when the New Left was a political lonely hearts club, at the expense of the mid and late Sixties, which is when the New Left was a mass movement. So I think it's necessary for historians in this field to use some of the methodologies and approaches of social history, and focus more upon the rank and file activists at the grassroots. This is something Paul Buhle and I tried to do with the essays we selected for The New Left Revisited. ${ }^{15}$ Almost every essay in that book is at least implicitly a response to the debate that Gitlin and Miller helped to provoke. That said, recently I re-read the introduction I wrote for that book, and it contains a few snarky asides that I've come to regret. Wini Breines, whose work I admire, wrote in a review of the book that the field need not become a site of generational conflict between scholars, and she's right of course. ${ }^{16}$

BH: Can you talk a little more about the work that you and others have done on that period, articulating a bit more about what you were attempting to do and how it was different from what others had done before?

JM: Well, take my friends Jeremy Varon and Mike Foley, who recently wrote books on revolutionary violence in the Sixties, and on draft resistance, respectively. ${ }^{17}$ These are huge topics that haven't really been examined before; they were hidden in plain sight. It's astonishing: one of the most salient facts of the Sixties, Jeremy points out, was that there was this functioning revolutionary discourse that drew so many people into its fold. By one survey, something like a million people in 1969 self-identified as "radicals" or "revolutionaries." How did so many people 
decide that American society was rotten at its core and could be rebuilt anew? It's a puzzling thing because in the Sixties in the US, there were important social problems but also, the US was a prosperous superpower, the envy of much of the world, an affluent society, a formal democracy [...] and yet there was a wholesale rejection of the entire society. And so for Jeremy, that was his thing, why has there not been more attention paid to this? For Mike Foley, the same thing, draft resistance was a huge part of the movement and it's barely figures in the scholarly literature. In my work, I'm trying to show that the era's underground papers were hugely important, yet they too haven't received a lot of attention.

We were talking a bit earlier about de-centering SDS. I want to suggest that the vast majority of people who passed through the New Left must have been exposed to its polemical writings, and especially, its underground papers, which were ubiquitous in the late $1960 \mathrm{~s}$. Radical papers afforded a community for radicals that SDS and some of these other groups didn't. Oftentimes they were what spoke most directly to radicals, not SDS. Instead of viewing the New Left as an over-arching youth rebellion, it's helpful to regard it as a constellation of different "scenes"- that is, enclaves in radical or hip communities in different places, which were generally interconnected through these radical papers. So I'm exploring with another way of narrating the Sixties from a "bottom up" perspective, a grassroots perspective, rather than a top down one, which was the old guard's approach. Others are doing the same thing: Andrew Hunt, writing about Vietnam Veterans against the War (VVAW), a group that he sees as really important that's been excluded from the literature. ${ }^{18}$ So this is what people are doing, looking at unexamined phenomena. Doug Rossinow wrote that big book about the New Left in Austin, Texas. ${ }^{19}$ Austin had one of the largest radical communities in the country, and it was very interesting because they bridged the strategic politics of the New Left with the cultural politics of the counterculture in a unique and exciting way. And until Doug picked it up, that topic was just laying fallow. And he did this great, massive book about it.

BH: It's striking that the academics you've identified as doing the new scholarship on radicalism in the Sixties are all males. Why do you think that's the case? What innovative scholarship on the New Left are we seeing on this time period from female scholars?

JM: Well I've mostly been talking about people who study the New Left, specifically, as opposed to the counterculture, or feminism, or the Sixties more generally. All of these fields overlap, but they're not one and the same. But even so, of course there are important female commentators upon the New Left, like Alice Echols, Jennifer Frost, Beth Bailey, Robbie Lieberaman, Francesca Polletta. One of the best dissertations I've ever read is by Wesley Hogan, comparing SDS and the Student Nonviolent Coordinating Committee $[\mathrm{SNCC}] .{ }^{20}$ It's funny you men- 
tion this, because before the New Left Revisited was even published, its table of contents circulated on a listserv- "Women-in-Action," I think it's called-and someone noticed that of the fifteen contributors (including me and Paul) only three were women. So I got a torrent of sharp emails, from Katha Pollitt, Marge Piercy, Rosalyn Baxandall, and others, asking "How could you leave women out of the New Left? " I thought this was a little unfair. For one, some of the male writers in the book, most notably Mike Foley, specifically addressed gender dynamics in the Movement. What some of my critics were really suggesting is that we ought to have included essays about radical feminism, and I don't think feminism was a part of the New Left. To the contrary, the New Left was largely a male-dominated movement. Whether women were muscled aside or simply acquiesced to prevailing gender stereotypes is up for debate, but most anyone would agree that men were in the lead of most New Left organizations, and women did more than their share of the shit work-cooking and cleaning, clerical chores, bookkeeping, and so forth. Feminism emerged in response to the chauvinism that women encountered in the New Left and the Civil Rights Movement, and by deliberately seceding from the Movement they launched a hugely important revolution of their own. So I see the New Left and feminism as two discrete movements that overlap a bit.

BH: Do you think this new scholarship has helped to shape people's feelings about the period?

JM: Yes and no. Everyone who seriously studies postwar American history recognizes — or ought to recognize- that there's a new wave of revisionist scholarship underway, but it hasn't yet been synthesized into a new narrative. That'll happen eventually, but it's going to be very hard to do because there's so much ferment in the field, and so much that remains to be explored. I think people need to do a lot more work, looking at these unexamined areas, and then from the perspective of hindsight, many years down the road, someone can write a new comprehensive overview.

BH: With this recent scholarship, you've talked about some of the impact that it's had, but what about outside of the academy? Has there been an attempt by you and other young writers to bring what you're presenting outside of the academy? And what is there to learn for people who are involved in activism-what can people take from this scholarship?

JM: Those are two different questions. First, I'd say the new scholarship hasn't yet filtered into the mainstream or the popular understanding of the Sixties. And in fact, if you look at a lot of American history textbooks you find that cover the New Left in a pretty glib and condescending way. ${ }^{21}$ But this isn't so surprising. After this fervent debate within the academy, that not many people are going to be 
privy to, some new, shared understanding will result, and eventually this will trickle into the textbooks and whatnot. I think that when a lot of people who were involved in the '60s die, this will be easier accomplished (langhs). But seriously, Louis Menand made this point in a New Yorker essay: The field could really use the attention of people who care a little less about whether the Sixties was a good thing or a bad thing. ${ }^{22}$ This is a field that people are unusually personally invested in. And a lot of people, like myself, and others I've just mentioned, we share a lot of the assumptions that animated the New Left-about the moral and political tragedy of the Vietnam War, the unfairness of racism, the existential rewards of a committed life. And then there are also some historians who have very jaundiced attitude toward the New Left, who think it was unhealthy and destructive. I take these arguments seriously, although as I sometimes point out, no one in the New Left killed millions of people in a senseless war. Anyhow, I think that in some future era, when people have the perspective of hindsight and a little more detachment, maybe we'll get a new narrative.

You also asked what activists can learn from this new scholarship. I get asked this question a lot, and I never have a good answer. Certainly New Leftists made lots of obvious mistakes. They were generally arrogant; they alienated some of those who might have been sympathetic to their position; and they underestimated the dangers of provoking a backlash from the defenders of the established culture. They directed too much indiscriminate animus toward "the Establishment" that, in hindsight, wasn't always well theorized. Recently, I've also become a little dubious about some of the hyper-democratic, collective organizing models that New Leftists used, where meetings lasted forever, and even informal leaders or hierarchies were distrusted. Maybe these approaches were better in theory than practice. It's also important to recognize the great lengths that authorities went to destroy the movement. There's never been a radical movement in American history that wasn't subjected to fierce official repression, and activists today need to be mindful of this. Finally, I think present-day activists would do well to remember that New Leftists and counter-culturalists had lots of fun. That was key.

BH: You've written about radical graduate students during the Sixties as being particularly concerned that their research and writings should be relevant to political organizing of the time, as well as to later periods, something that Paul Buhle has described as writing "love letters to the future. " Can you discuss that notion a little bit?

JM: It's a really beautiful notion. It's the idea that - and I think he wrote this in sixty-nine, when the movement seemed to be collapsing all around him-he would remain committed to his scholarship and his work. His idea was, "The movement isn't going to play out the way we want to right now, but we can still do this work 
and it's still serious and purposeful, and some day maybe people will pick it up and put it to some good use." So he began thinking of the academic work that New Leftists were doing as love letters to the future.

BH: Do you see any aspect of that in your work, in terms of affecting people and movements?

JM: One thing that interests me is how difficult it has been for people to build mass democratic movements in this country. It's just not an easy thing to do. For people in the Sixties to build this highly stylized protest culture with hundreds of thousands of people or millions of people involved-regardless of whether you think the New Left was a good thing or a bad thing - this was a considerable tactical achievement! The fact that they broke away from the resignation and apathy of the larger society and built this movement-that's an amazing thing. In my work on the underground press I try to reflect a bit about how that happened. So if this ends up becoming a contribution to our understanding of how mass democratic movements happen, and maybe down the road someone can study or learn from or apply my work in a practical way, that would be wonderful. But I don't know if scholarship always works exactly like that.

BH: But it seems like you've also intentionally published a lot of material in the public arena. Is there a reason that you've done that?

JM: That's kind of you to say; others have done much more. But the Radical Reader was certainly designed to bring about more charitable perceptions of the role that radicalism plays, and to encourage teaching about radicalism in secondary schools and colleges, and that's happened to a considerable degree. ${ }^{23}$ The book is already being used in lots of courses, at universities like Harvard, Columbia, Georgetown, and elsewhere. And I've always wanted to write for a public audience, rather than solely for academics, because that's the most likely way that one's work is going to have lots of agency. If you only are communicating to other scholars, and your prose is difficult and inaccessible, then it's not going to be as relevant as that which gets read and understood by a wider audience. I'll always hope that my writing will be appealing to the general reading public, not just academics.

BH: I'd like to talk about radical history for a little bit. It seems like the terms "radical history" and "radical historian" are used a lot in the discipline, and while it's not necessarily something that's encouraged across the board, the study of things radical, at least from my perspective, seems to be more accepted in History than most other disciplines. However, it also seems that what "radical history" or what a "radical historian" is varies quite a bit. To what extent do you identify as a 
radical historian, if at all, and if you do, what has that identification or that concern with that identity meant to you?

JM: I think of myself as radical in the sense that my political views are pretty far outside of the mainstream. I find little of promise in even the liberal wing of the Democratic Party, so I identify as a radical in that respect. But I don't think of myself as a "radical historian" in the sense that my methodologies or approaches are unconventional. I do what I think is pretty straightforward social and cultural history. I am not going to experiment with any paradigm busting approaches or unusual styles of writing. Now, I think I'm pretty impassioned about what I do, and so that shows a little in the writing, in my prose style. Anyone who reads my work would discern a certain commitment or excitement about the material. But that's as far as it goes.

BH: Has your positioning as a radical ever been in issue, as a historian or outside of the academy?

JM: The academy is pretty left wing. So I am not persona non grata for studying American radicals in the academy. And I can't say that I've even been inconvenienced either, except for being forced to argue with people who disagree with me about political things. Like in the Nader election, I continued to support him when most of friends and a lot of people I know thought that that was absurd. I was campaigning for Ralph Nader in 2000 on the Upper West Side. 10027 is maybe the most Democratic zip code_-probably there's more Democrats there than anywhere else in the world - and so I would get yelled at and abused by passers-by (laughs). But I think I gave as good as I got.

BH: Jesse Lemisch wrote recently that "Activism shows us how it is that people told that there is no alternative to the way things are, can, in fact, invent new alternatives, particularly in the streets and on the pick lines. You can't begin to understand how history happens unless you have this basic training as a historian/activist. A good dose of tear gas makes us think more clearly as historians. ${ }_{24}$ I'm curious what you think of this statement.

JM: I like it. I think it's a more articulate, eloquent way of saying what I was trying to suggest before, which is that much of history is made by people who aren't captains of industry, or military generals or politicians or leaders or whatnot. Lemisch is very much committed to social history - to the idea that the driving forces of society, the people who have agency, are often people who are marginalized or oppressed. You get a different version of American history if you listen to the voices of poor people or minorities or criminals or people who have somehow been shut out from the promises of the American dream. And it's inspiring 
to see that throughout history, over and over and over again, movements for social change have come from the bottom up. I think that he realizes that and that that's a wise insight.

BH: But I think he's also speaking to the actual role of the historian and the historian having activist experience as a way of engendering and reinforcing an understanding of how these changes take place.

JM: Right, the part about the tear gas.

BH: Yes. Does that resonate with you?

JM: I think I can understand this on an intellectual level even if I haven't been tear-gassed. Something like that could remind a person that powerful social movements in this country have always been met by resistance from the people in power. All of the movements that celebrate today-abolitionists, trade unionists, civil rights activists, all faced incredible resistance. And so that's an insight that a scholar should have. And more generally speaking, I think he's right if he's suggesting that it's important for scholars to have some real-world experience outside of the ivory tower.

BH: What about the activist/academic divide or dichotomy that some people seem to make it into. Is that something that you think about; is that something that you struggle with at all?

JM: Eugene Genovese once said something about how it's very difficult to be both a scholar and an activist. To do either of these things very well one needs to make a full-time commitment to one or the other. That is, you can't be a decent scholar if you only do it only as time and circumstances allow, and you're involved in all these sorts of political activities. And there is something to be said for that, but I think it's overstated. Working on the union was a bit of a sacrifice, though. I was constantly feeling guilty because I wasn't reading as much as I should (laughs). I was supposed to be studying for my orals but instead I walking around campus, passing out fliers and talking to students and attending meetings that went on forever. That was a pretty big time commitment but it didn't derail my career or anything. I spent too much time at the bar, too.

BH: I want to go back to something that you wrote about graduate students a few years ago. You're wrote that "if today's history graduate students truly want to imitate their professors - as frequently seems the case - then we might start by becoming more unabashedly political, by enlarging our notions of academic citizenship, and by looking for new ways to pursue the twin ideals of scholarship and 
social justice. " ${ }^{25}$ Can you discuss this?

JM: It's interesting to me that so many graduate students are in awe of their professors. They see them as sort of models and yet, a lot my peers seem unaware of the ways that so many of the leading historians of today were politicized by the Sixties. And yet a lot of graduate students today don't have a sense of academic mission behind their scholarship; so if grad students today want to emulate their professors they should probably not be so reticent about becoming political[ly] engaged. This is just anecdotal, but look at the American historians at Columbia: Anders Stephanson, Manning Marable, Betsy Blackmar, Alice Kessler-Harris, and Eric Foner-these are people who have shown a great deal of political commitment throughout their lives and they've done scholarship that was meant to be politically relevant. But only rarely did I ever run across history grad students at Columbia whose work was guided by a keen sense of political mission. Whereas, it used to be the case that scholarship was supposed to be politically relevant. In the Sixties, this was crucial. There was this very strict demand placed on the writing of New Leftists- "What is this work for? And if you can't tell me how this work is going to help us to build a movement for social change, or how it's related to problems that trouble American life_-if you can't answer this question then there's something wrong with what you're doing. You need to rethink why you're spending your energy in this way." That was the attitude. And today those questions aren't often put to young historians. Maybe they should be.

John McMillian can be reached at momill@fas.harvard.edu.

\section{Notes}

1. Jeremy Varon is an associate professor of history at Drew University and the author of Bringing the War Home: The Weather Underground, the Red Army Faction, and Revolutionary Violence in the Sixties and Seventies (Berkeley: University of California Press, 2004).

2. Dave McBride received his Ph.D. in American history from UCLA. His dissertation was on counterculture in Los Angeles during 1960s. He is a senior editor at Oxford University Press.

3. Kevin Mattson is Connor Study Professor of Contemporary History at Ohio University. $\mathrm{He}$ is also the author of Intellectuals in Action: The Origins of the New Left and Radical Liberalism, 1945-1970 (University Park: Penn State Press, 2002) and several other books.

4. John McMillian, "Columbia Diary: A Personal Odyssey in African American Studies," Souls 6: 3-4, (2004), 67.

5. John McMillian, "Where Have All the Politics Gone?: A Graduate Student's Reflections," in Taking Back the Academy: History of Activism, History as Activism, eds. Jim Downs and Jennifer Mansion (New York: Routledge, 2004), 86.

6. Beverly Gage received her Ph.D. in History from Columbia University and is an Assistant Professor of History at Yale University.

7. Kimberly Phillips-Fein teaches economy, history and culture at New York University. 
She has written for The Baffler, The Nation, New Labor Forum, Newsday, and In These Times, among other publications.

8. Jennifer Fronc received her Ph.D. from Columbia University and currently teaches in the History Department at Virginia Commonwealth University.

9. John McMillian, "Love Letters to the Future: REP, Radical America, and New Left History," Radical History Review 77: (2000): 20-59.

10. John McMillian, “'History Makes Its Demands': Identity Politics, Slavery Scholarship, and the Narrative of Robert Starobin," Rethinking History 6: 2 (2002): 151-174.

11. John McMillian, "Black Like Me." Review of White Boy, by Mark Naison, The Nation, 275: 3 (July 15, 2002): 42-44.

12. Johanna Fernandez is an Assistant Professor of History at Carnegie Mellon University.

13. Todd Gitlin, The Sixties: Years of Hope, Days of Rage (New York: Bantam Books, 1987).

14. James Miller, "Democracy is in the Streets": From Port Huron to the Siege of Chicago (New York: Simon and Schuster, 1987).

15. John McMillian and Paul Buhle, eds., The New Left Revisited (Philadelphia: Temple University Press, 2003) .

16. Review of The New Left Revisited, by Wini Breines, American Journal of Sociology, 109: 1 (2003): 509-511.

17. Michael S. Foley is Associate Professor of History at the City University of New York's College of Staten Island and author of Confronting the War Machine: Draft Resistance during the Vietnam War (Chapel Hill: University of North Carolina Press, 2003).

18. Andrew Hunt is an Associate Professor of History at the University of Waterloo in Waterloo, Ontario and is the author of The Turning: A History of Vietnam Veterans against the War (New York: New York University Press, 1999) and Nonviolent Revolutionary: The Life and Times of David Dellinger (New York: New York University Press, 2005).

19. Doug Rossinow is Associate Professor of History at Metropolitan State University, Minneapolis and is the author of The Politics of Authenticity: Liberalism, Christianity, and the New Left in America (New York: Columbia University Press, 1998).

20. Wesley Hogan, "Radical Manners: The Student Nonviolent Coordinating Committee and the New Left in the 1960s," (Ph.D. diss., Duke University, 2000).

21. See Bruce J. Schulman, "Out of the Streets and Into the Classroom? The New Left and the Counterculture in United States History Textbooks," Journal of American History 85 (1999): 1527-1534.

22. See Louis Menand, "Life in the Stone Age," in Menand, ed., American Studies (New York: Farrar, Straus and Giroux, 2002), 162.

23. Timothy Patrick McCarthy and John McMillian, eds., The Radical Reader: A Documentary History of the American Radical Tradition (New York: The New Press, 2003).

24. Jesse Lemisch, "2.5 Cheers for Bridging the Gap Between Activism and the Academy; or, Stay and Fight: To Which is Added an Account of Radical Scholar-Activists in the Wake of the Iraq War," in Jim Downs and Jennifer Manions, eds., Taking Back the Academy: History of Activism, History as Activism (New York: Routledge, 2004), 188.

25. John McMillian, "Where Have All the Politics Gone?," 89. 


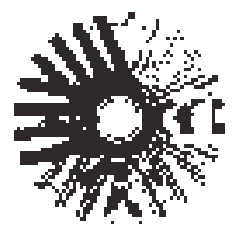

\title{
CANADLAN COMMITEE ON LABOUR HISTORY
}

\section{JOURNAL OF CAMADIAAN LAEDUR STUDIES}

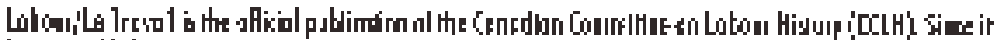

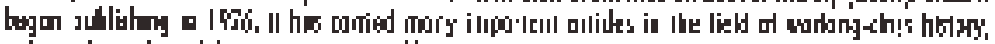

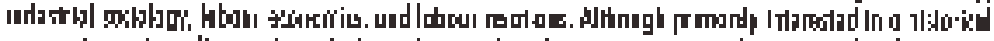

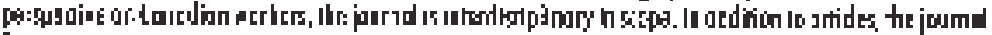

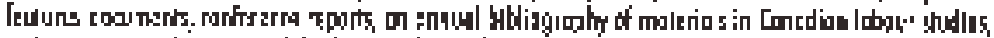

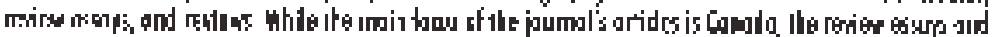

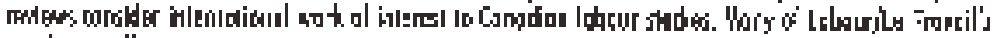
aliker a

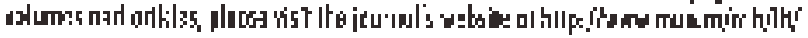

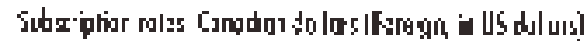

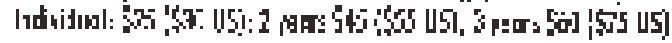

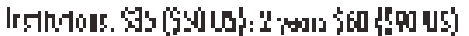

So:

\section{BOOKS: RECENT PUBLICATIONS OF THE CCLL}

$\therefore$ P.EN LFIFISF -

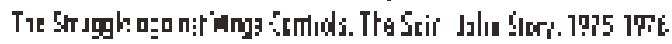

[is:

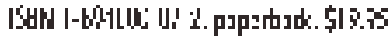

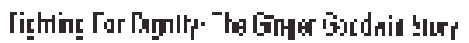
Pisar Shomernks

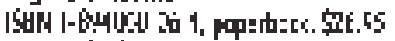

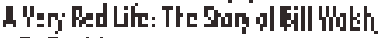
[x [on]in:

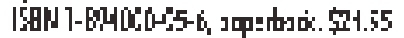

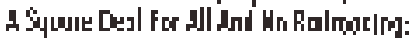

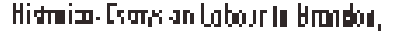

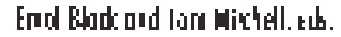

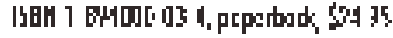

\author{
A H: Hor

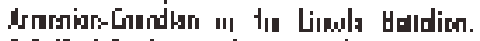

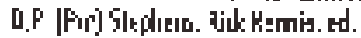

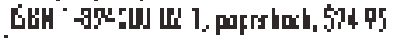 \\ The Himen werker, : 42 - 1$\} 2$ ? \\ .

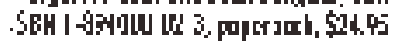

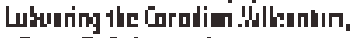 \\ Brima piolater ed

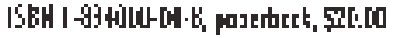

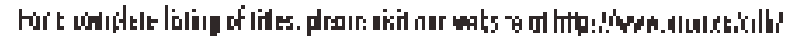

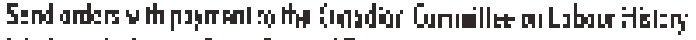

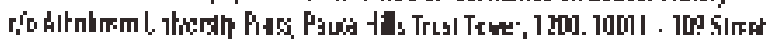

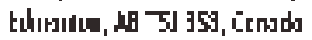

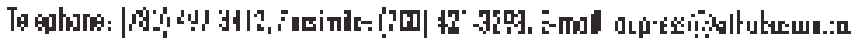

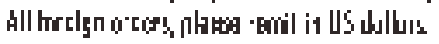

